\title{
DEVELOPMENTAL ASPECTS OF INNOVATION IN PRESCHOOL EDUCATION
}

\section{Nebojsa Cvetkovic ${ }^{31}$, Boban Tomic ${ }^{32}$, Marija Vukic ${ }^{33}$}

\begin{abstract}
This work is based on the modern institutional concept of the preschool physical education programme, which is realized in the kindergarten "Sunce" courtyard, in the preschool institution "Jelica Obradović" in Mladenovac. Namely, in the courtyard of the mentioned kindergarten, an innovative system for physical exercise named "Sun's Playroom - Planetary Polygon" was constructed and installed. Two groups of children of the same age, with different motor experiences, were practicing daily for 30 minutes, on the mentioned system, for 20 days. An assessment of children's motor skills on the given system was performed at the beginning and at the end of the cycle. In addition to the assessment of motor skills and the control level over motor functions, the cognitive process of information acquisition and the level of communication and socialization among children were also monitored. The conclusion reached is that this kind of a new complex for exercise and learning in the open space has a significant impact on the development of psycho-motorics in children, as well as on the cognitive functions, cultural and communication skills.
\end{abstract}

KEY WORDS: educational management, innovation, motoricity, development, communication, socialization

JEL: A20

UDC: 371.3:001.895

373.2

COBISS.SR-ID 272228364

\footnotetext{
${ }^{31}$ Faculty for Communications, Belgrade, Serbia, cvetkovic.nebojsa10@ gmail.com

${ }^{32}$ Faculty for Communications, Belgrade, Serbia

${ }^{33}$ Center for Media and Communication Studies, Belgrade, Serbia
} 


\section{INTRODUCTION}

Movement represents a natural and one of the basic human characteristics formed during the evolution as a set of differentiated traits that determine effectiveness, hence this complex phenomenon requires a multidisciplinary approach in the study. Human movement (human locomotion) can be considered from a biological, physiological, biomechanical, sociological, psychological, and pedagogical aspects. At the same time, with the establishment of the upright walking of the first people, a different thinking and a world view started to develop in comparison to the one of man's four-legged ancestors. So, physical-motor changes are closely related to the psychological and thinking changes that people have been going through during their evolution, and it leads to the conclusion that the synergy of these two processes is a basic precondition for the development of both an individual and the society as a whole.

In spite of the fact that the toning effect of a movement, which can be observed from the baby's first steps, is proven, involving the first games related to the irreplaceable motor activities, that is, the first moments of physical exercise and its effects on the developing organism, the children of today are spending more and more time in so-called passive positions, sitting and lying. Such habits keep them away from their natural need for movement and substantially reduce the majority of physical and functional abilities (Cvetković, N., 2010., p.10). Worldwide, this phenomenon is referred to by experts as hypokinesia, or a lack of movement. This deficiency is also reflected on the psychological development of a child, who in isolated environments and infrequent direct contacts with its peers, is exposed to the reduced space for communication and interaction that is important for the psychological and cognitive development of a child, as well as the habits forming related to social, cultural and social activities and interactions.

One of the places where it is possible to improve regularly planned, systematic exercise, the culture of living, communication and social interaction are schools and kindergartens. That is why, in recent years, there has been an increase of attention to school and preschool physical exercise on the global level. Through physical exercises, children develop and encourage receptors mechanisms that lead to the strengthening of communicative relations among the members of the same community or generation, resulting in the acquiring of new knowledge and the strengthening of personal and collective communicative and social competences.

The extent to which the exposure to the movement is important was also indicated by McGrow's research in 1935., conducted on the monozygotic twins, the children in an early childhood, in which it was found that stimulating environment and more frequent exercise of different motor skills affect better performance and self-confidence. In other words, early exposure to movements, in addition to playing an important role in acquiring and retaining various motor skills, also influences the acquisition of some psychological characteristics important for further comprehensive development of children.

This paper presents the results of the continuous testing and measuring of the effects of a new way of spatial and content organization of the children's polygon on the psycho-physical, social and communicative competences in children. By establishing a clear and measurable link between the innovation in the didactic furnishings of the preschool institution and strengthening of the psycho-physical, social, cultural and communicative abilities in children, the paper clearly points out the importance, efficiency and effectiveness of this new approach in the management of a preschool education. This model provides a possibility for application and replication in higher educational cycles - primary and secondary schools. 


\section{MULTIFUNCTIONAL POLYGON}

In the Preschool institution "Jelica Obradović" in Mladenovac, a completely authentic and innovative children's gym was constructed - a polygon, consisting of nine devices - playgrounds, representing planets (Figures 1, 2, 4) and the central device, representing the Solar System (Figure 3). The central part of the central device is the Sun, which is a fixed part of the device, while the moving part of the device that revolves around the Sun holds the representations of the Solar System's planets, marked by ordinal numbers.

The central device has two sides (front side and the reverse), and in this way it is possible to include in the game a larger number of participants, divided into groups, from five to seven children. All devices are made of wood, painted with ecological colors, and their constituent parts are constructed to allow the change of their position (raise, lower or rotate) and thus increase or decrease the mastering process of the device in question.

Children find this type of playground in the open space very interesting and attractive for playing and motor development, and in addition to the mentioned contents, it allows for a longer stay in nature and learning in the open space. Such organization of didactic equipment, from the point of view of the educational management, enables better insight, control and monitoring of children's activities by the educators.

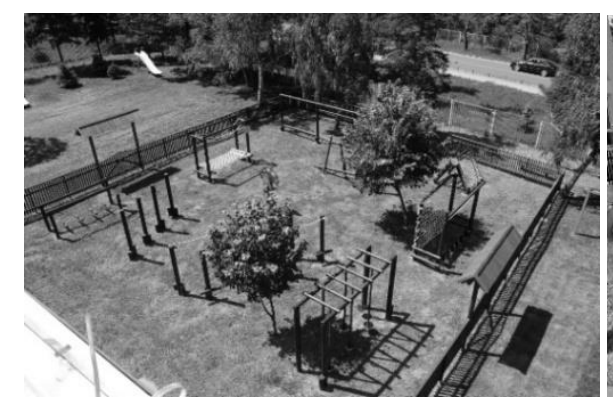

Figure 1.

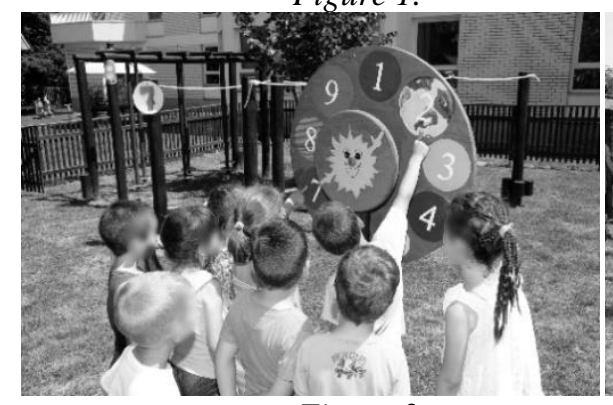

Figure 3.

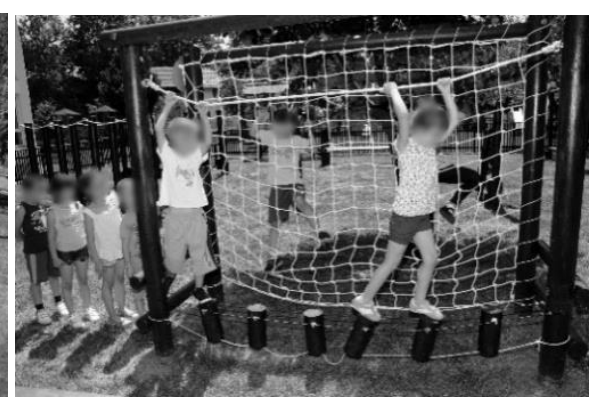

Figure 2.

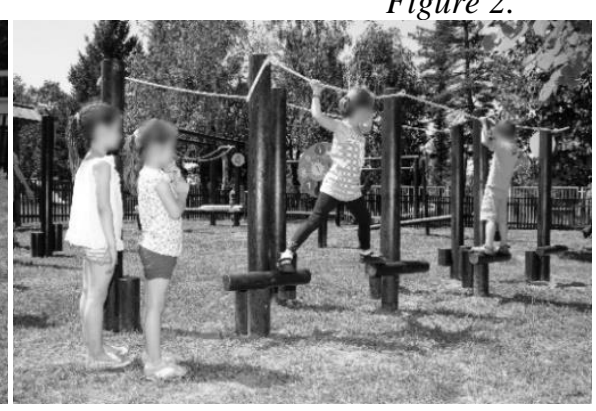

Figure 4.

\section{MONITORING OF MOTOR SKILL ACQUISITION}

"The use and determination of criteria for the assessment of motor development are based on the observation that most children go through the same stages in mastering the motor skills (maintaining body position, locomotion, capturing and holding objects). Basic similarities in these stages in children indicate that hereditary and genetic factors have a significant impact on 
the development of motor skills that are essential for survival. The second aspect of human development indicates the existence of sensitive periods during which the child is most susceptible to certain motor skills acquisition "(Abernethy and others 2012, p. 242).

"All programmes designed to improve the early development of motor skills in children are based on the assumption that the early reaching of criteria for assessing motor development is useful for the long-term acquisition of motor skills" (Abernethy and others, 2012, p. 244). Therefore, there is substantial scientific evidence that in stimulative environments which have diverse and interesting training stimuli for children, the possibilities for accelerated motor learning through movement and play are virtually unlimited, that is, it is possible to accelerate the pace of motor development for the given age. This theory of accelerated motor development relates to fundamental patterns of motor skills, such as running, jumping, walking, maintaining balance, etc. (phylogenetic forms of movement), as well as to the non-locomotor skills, that is, those movements that are learnt and are not conditioned by the development of a given species (ontogenetic forms of movement). In analogy, psychological development, as well as the building of social communication in the group, interpersonal and group communication of children among themselves, strengthen the overall development of the personality and create a strong base for building other forms of sociability, especially the culture of learning and science. In this sense, the didactic planetarium that promotes motor development has far reaching positive effects on the psycho-social, cultural and social life of a child.

\section{ASSESSMENT TABLE}

\begin{tabular}{|c|c|c|}
\hline No. & MOTOR HABITS & $\begin{array}{l}\text { DEVELOPMENT } \\
\text { LEVEL }\end{array}$ \\
\hline 1 & There is no given movement & \multirow[t]{2}{*}{ First level } \\
\hline 2 & $\begin{array}{l}\text { Trying to perform the movement } \\
\text { unsuccessfully }\end{array}$ & \\
\hline 3 & $\begin{array}{l}\text { Performs a movement with support and/ } \\
\text { or assistance }\end{array}$ & \multirow[t]{2}{*}{ Second level } \\
\hline 4 & $\begin{array}{l}\text { Performs a movement with an incomplete } \\
\text { movement range, independently }\end{array}$ & \\
\hline 5 & Exercises the basic movement technique & \multirow[t]{2}{*}{ Third level } \\
\hline 6 & Improves the movement technique & \\
\hline 7 & The movement is coordinated & \multirow[t]{2}{*}{ Fourth level } \\
\hline 8 & Movement is performed at different paces & \\
\hline 9 & $\begin{array}{l}\text { Tries out a skill with aggravating } \\
\text { movements }\end{array}$ & \multirow[t]{2}{*}{ Fifth level } \\
\hline 10 & $\begin{array}{l}\text { Combines movements with other skills, } \\
\text { competes }\end{array}$ & \\
\hline
\end{tabular}




\section{FINDINGS ANALYSIS}

1. Estimated motor status of a group of children aged 5-6 years (Table 1), who spent 3 years in kindergarten and used the resources of the kindergarten, the Sun, and for the first time practiced on the specific playground, the Sun's Playroom - Planetary Polygon, a total of 28 children. Estimated amount of acquired new information, in this case is primarily related to the planetary system.

2. Estimated motor status of a group of children aged 5-6 years (Table 1), who did not stay in the kindergarten and did not have regular exercises, and who practiced for the first time on a specific training system, the Sun's Playroom - Planetary Polygon, a total of 25 children. Estimated amount of acquired new information, in this case is primarily related to the planetary system.

3. After 20 days of daily exercise, lasting for 30 minutes, the motor status of the first group of children was measured.

4. After 20 days of daily exercise, lasting for 30 minutes, the motor status of the second group of children was measured.

\section{ASSESSMENT AND MEASUREMENT}

\section{Duration of the assesment is 20 working days}

- The first group of 28 children of pre-school age (in kindergarten for 3 years)

- The second group of 25 children of pre-school age (newly enrolled children)

\section{Initial measurement}

Group I

- LEVEL 2 (movement in the basic phase of formation) 10 children

- LEVEL 3 (exercises basic movements) 18 children

Group II

- LEVEL 1 (no given movement) 2 children

- LEVEL 2 (movement in the basic phase of formation) 17 children

- LEVEL 3 (exercises basic movements) 7 children

\section{Final measurement}

Group I

- LEVEL 3 (movement in the basic phase of formation) 5 children

- LEVEL 4 (stabilized movement, moves at different paces) 17 children

- LEVEL 5 (moves at different paces, competes with oneself and others - gifted children) 6 children

Group II

- LEVEL 3 (practices basic movements) 11 children

- LEVEL 4 (stabilized movement, performs movements at different paces) 12 children

- LEVEL 5 (performs movements at different paces, competes with oneself and others gifted children), 2 children 


\section{CONCLUSIONS}

Two groups of children of the same age, with different motor experiences, were practicing daily for 30 minutes on a set didactic system, for 20 days. An assessment of children's motor skills was performed at the beginning and at the end of the cycle. In addition to the assessment of motor skills and the degree of control over motor functions, the cognitive process of information acquisition and the level of communication among children were monitored.

1. In the first group of children who were exposed to organized exercises in the kindergartens over a longer period (more than two years), higher developmental level of motor learning was observed. This phenomenon can be interpreted in such a way that the children of the given group had memorized more motor programs and had more acceptable motor behavior than the children from the second group, who met with organized institutional training for the first time. Also, according to the observations of the primary educators and according to the records in the children's portfolios, the children from this group were more willing to communicate with one another and they more exercised the verbal exchange. The level of social interaction (play, conversation, asking questions, expressing emotions, empathy...) is significantly better and evidently improved.

2. For twenty days, which was the duration of the experiment, both groups demonstrated significant progress, of two developmental levels on average.

3. Considering the two-level difference between the initial and the final measuring, which represents a significant improvement in the twenty days of exercises on a programme system of the specific sport-didactic funrnishings, it can be concluded that these types of training systems have a very strong impact on the development of psycho- motor skills in children, as well as on the social skills. The above is based on the assumption that the Sun's Playroom, as a programme system, had an extremely motivating effect on children, because the activities were realized through play. The children exercised in conditions of certain instability, which required additional engagement of the nervous-muscular system and the proprioceptive apparatus, as well as the cognitive and communicative functions, and a higher degree of cooperation among the educators. In this way, the adoption of new motor assignments was realized faster, incidence of errors was less frequent, and general motorics and cognitive processes demonstrated faster improvement.

4. In addition to the motor improvement, the exercise on this type of sport-didactic furnishing, also created an interest in children for the various aspects of the educational work (mathematical concepts, spatial relations, knowledge of planets and the solar system, social relations, cultural habits, etc.) through self-initiated stimulus and initiation of verbal communication.

5. A new table for monitoring of motorics in children (motor habits, motor learning) proved to be very precise, easy to use, and the monitoring of child's progress in this way also provided some data that are compatible with each other and influence the stimulation of motorics in children, self-awareness, awareness of others and the environment in which they exercise (sociomotor behavior), which will be the subject of some other research. 


\section{REFERENCES}

[1] Abernethy, B., Hanrahan, S., Kippers, V., Mackinnon, L., Pandy, M. (2012): Biofizičke osnove ljuskog pokreta, Data status, Beograd

[2] Amazone adventure-createur park d aventure-Google

[3] Grupa autora, (2012): Dečji sport od prakse do akademske oblasti, Fakultet sporta i fizičkog vaspitanja, Univerziteta u Beogradu

[4] Cvetković, N. (2010): Vežboteka sa osnovama lokomotornog sistema i motornog učenja, Publik prektikum, Beograd

[5] Cvetković, N. Cvetković, J. (2017), „Spajdilend-praćenje i razvoj dečje motorike“, XII Simpozijum „Vaspitač u 21. veku“, Soko Banja.

[6] Sharkey, B., Gaskill, S.(2008): Fitnes and health, Data status, Beograd

[7] www.pujelicaobradovic.edu.rs

\section{Article history:}

- Received 5 September 2018

- Accepted 28 November 2018 